University of Nebraska - Lincoln

DigitalCommons@University of Nebraska - Lincoln

Faculty Publications, Department of Psychology

Psychology, Department of

April 1994

\title{
Social Networks and Daily Activities of Street Youth in Belo Horizonte, Brazil
}

\author{
Regina Campos \\ Universidade Federal de Minas Gerais, Belo Horizonte \\ Marcela Raffaelli \\ University of Nebraska-Lincoln, mraffaelli1@unl.edu \\ Walter Ude \\ Universidade Federal de Minas Gerais, Belo Horizonte \\ Marilia Greco \\ Universidade Federal de Minas Gerais, Belo Horizonte \\ Andrea Ruff \\ Johns Hopkins University, aruff@jhsph.edu \\ See next page for additional authors
}

Follow this and additional works at: https://digitalcommons.unl.edu/psychfacpub

Part of the Psychiatry and Psychology Commons

Campos, Regina; Raffaelli, Marcela; Ude, Walter; Greco, Marilia; Ruff, Andrea; Rolf, Jon; Antunes, Carlos Mauricio; Halsey, Neal; Greco, Dirceu; Jeronymo, Mauro; Kendall, Carl; Merritt, Alice Payne; Pinto, Jorge Andrade; Siqueira, Eliana; and de Zalduondo, Barbara, "Social Networks and Daily Activities of Street Youth in Belo Horizonte, Brazil" (1994). Faculty Publications, Department of Psychology. 133.

https://digitalcommons.unl.edu/psychfacpub/133

This Article is brought to you for free and open access by the Psychology, Department of at DigitalCommons@University of Nebraska - Lincoln. It has been accepted for inclusion in Faculty Publications, Department of Psychology by an authorized administrator of DigitalCommons@University of Nebraska - Lincoln. 


\section{Authors}

Regina Campos, Marcela Raffaelli, Walter Ude, Marilia Greco, Andrea Ruff, Jon Rolf, Carlos Mauricio Antunes, Neal Halsey, Dirceu Greco, Mauro Jeronymo, Carl Kendall, Alice Payne Merritt, Jorge Andrade Pinto, Eliana Siqueira, and Barbara de Zalduondo 


\title{
Social Networks and Daily Activities of Street Youth in Belo Horizonte, Brazil
}

\author{
Regina Campos, Universidade Federal de Minas Gerais, Belo Horizonte \\ Marcela Raffaelli, Rutgers University \\ Walter Ude \& Marilia Greco, Universidade Federal de Minas Gerais, Belo Horizonte \\ Andrea Ruff \& Jon Rolf, Johns Hopkins University \\ Carlos Mauricio Antunes, Universidade Federal de Minas Gerais, Belo Horizonte \\ Neal Halsey, Johns Hopkins University \\ Dirceu Greco, Universidade Federal de Minas Gerais, Belo Horizonte \\ Street Youth Study Group: Mauro Jeronymo, Carl Kendall, Alice Payne Merritt, \\ Jorge Andrade Pinto, Eliana Siqueira, and Barbara de Zalduondo
}

\begin{abstract}
Social networks and daily activities of children and adolescents living and/or working on the streets of a large Brazilian city were examined. Drawing on data collected through structured surveys, in-depth interviews, focus group discussions, and field observations, we described street youths' family situation, social resources, institutional experiences, survival activities, and problem behaviors and investigated differences attributable to age, gender, and living situation (at home or on the street). Youngsters who lived at home and worked on the street appeared to be experiencing orderly development despite their impoverished circumstances. Youngsters who lived on the street showed hallmarks of psychological and physical risk, including parental loss, diminished social support, substance abuse, and early onset of sexual activity. Possible implications of these contextual differences for development are discussed, and directions for future research suggested.
\end{abstract}

This research was supported by National Institute of Mental Health Grant MH45237. Portions of this paper were presented at the Society for Research on Adolescence, March 1992, and the International Conference on AIDS, July 1992. We thank the youth agencies who permitted us to work at their sites and the children and adolescents who shared their stories with us, and acknowledge the helpful comments of Felicia Barker Knaul and the anonymous reviewers. Address correspondence to Marcela Raffaelli.

Approximately 100 million children and adolescents are growing up on the streets of large cities worldwide (UNICEF, 1989). Two subgroups of street youth have been described (Barker \& Knaul, 1991; Lusk, 1989). Children "on" the street work at street-based jobs and return to their families at night or on weekends. Children "of" the street have fragmented family ties, sleep in street locations, and often engage in illegal survival activities. The ever-increasing presence of working and homeless street youth on city streets has been addressed primarily as a social problem, and little is known about these youngsters' devel- opmental trajectories. As a first step in attempting to understand the developmental implications of growing up as a street youth, we describe social and behavioral contexts of Brazilian working and homeless street youths' lives.

It has been proposed that what a child does, with whom, and where has far-reaching implications for development and that an analysis of daily life contexts can provide information about developmental trajectories (Bronfenbrenner, 1979). Interpersonal relationships give children the opportunity to engage in joint activities, obtain feedback, and form affective ties (Bronfenbrenner, 
1979). In most Western societies, parents (or parent substitutes) protect and guide children until they reach late adolescence (Damon, 1983); the lack of stable parental figures has been linked to a variety of negative outcomes (Kranzler, 1990; Roberts, 1974). Additionally, social support from family and nonfamily members may alleviate the negative impact of stressful events in childhood (Kimchi \& Schaffner, 1990). Thus, youths' ties to their families and the compensatory relationships they have access to are of developmental significance. How children and adolescents spend their time is important because participation in a variety of activities of differing complexity and scope provides youngsters with learning opportunities (Bronfenbrenner, 1979). Thus, the activities street youth engage in during their daily lives have the potential to influence their longterm development.

About two-fifths of the world's street youth are found in Latin America, with the majority in Brazil (Barker \& Knaul, 1991). Brazil is the fifth largest country in the world (population 150 million) and one of the richest nations in Latin America. However, much of the population is desperately poor, and many youngsters work to help support their families (Cervini \& Burger, 1991). Estimates of the number of working street children in Brazil range from 7 (Jovens miseraveis, 1990) to 17 million (Barker \& Knaul, 1991). Many other youth leave home and survive by scavenging, begging, stealing, or exchanging sex for money. The number of Brazilian homeless children is estimated at up to 7 million (Barker \& Knaul, 1991).

Most research on street youth has consisted of small-scale descriptive or demographic studies (for a review, see Barker \& Knaul, 1991). Rizzini and Rizzini (1991) reviewed 16 studies focusing on youngsters living and/or working on the streets of seven Brazilian cities. The majority of youth were male, between 7 and 17 years old, and started going to the street between the ages of 7 and 12. Most were from peri-urban slums and had parents; reasons for leaving home included economic necessity and family dysfunction. In a comparison of working and homeless street youth (Alves, 1991), few differences in family variables (e.g., composition, living situation, income) emerged, but more homeless youth had troubled interpersonal relationships and a history of school problems.

Given their living situations, it is likely that working and homeless youth have contact with different types of people and engage in different types of activities during their daily lives. In addition, male and female street youth of different ages will probably differ. Most research with street youth finds that boys greatly outnumber girls (Barker \& Knaul, 1991) and that most institutions are geared to street boys (Lusk, 1989). In light of this, and given the lack of data on this population, we felt it was important to examine gender and age differences in working and homeless youths' social networks and activities.

\section{Method}

\section{Sample}

Data were gathered in 1989-1990 as part of a larger HIV/AIDS prevention project targeting youth living and/or working on the streets of Belo Horizonte, the fourth largest city in Brazil (Payne Merritt \& Raffaelli, 1993). The study utilized multiple methods of data collection; samples studied with each method are summarized in Table 1 and described below. The target population was 9-18-year-olds who spend time on the street, working in the "informal economy" (e.g., selling food or flowers, washing cars, collecting paper) or engaging in illicit activities (e.g., stealing, drug dealing, exchanging sex for money). Youngsters were studied in different locations, including state and religious institutions, neighborhoods of origin, and the streets.

\section{Measures and Procedures}

Informed consent.-This research was authorized by the state juvenile court (juizado dos menores) which has jurisdiction over street youth, and was approved by institutional review boards. Verbal consent was obtained from participants.

Qualitative measures.-Focus group discussions (FGD) were conducted by three researchers (one male, two female) with 53 youth recruited through six state and religious institutions. Topics included family origins, life situation, sexual behavior, and drug use of street youth in general. Discussions were tape-recorded and transcribed.

Open-ended interviews were conducted by a female researcher with 15 youth in street settings and shelter houses. Again, topics included life situation and daily activities of street youth in general. Responses were hand-written and expanded after the interview. 
TABLE 1

Number and Ages of Youth Studied with Each Assessment Procedure

\begin{tabular}{|c|c|c|c|c|}
\hline & \multicolumn{2}{|c|}{ Boys } & \multicolumn{2}{|c|}{ GIRLS } \\
\hline & $N$ & Ages & $N$ & Ages \\
\hline 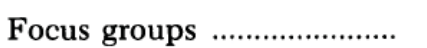 & 27 & $10-18$ & 26 & $13-18$ \\
\hline Open-ended interviews .... & 10 & $12-18$ & 5 & $12-18$ \\
\hline Life history interviews ....... & 4 & $14-20$ & 2 & $17-22$ \\
\hline Structured interviews ......... & 291 & $9-18$ & 88 & $9-18$ \\
\hline
\end{tabular}

Life history interviews were conducted by the same researcher with two young women and by a male researcher with four male youth. Youth were typical street youth previously known to the researchers. Interviews were audiotaped and transcribed.

Field observations were carried out sporadically over a 15 -month period in the youths' natural settings, including the city streets and squares where they spend their days, the highway overpasses and abandoned houses where they seek shelter at night or in inclement weather, and the open houses where they go for food and access to shower and laundry facilities. Ninety-three days of field notes were collected and transcribed.

Structured interviews.- Structured questionnaires were administered to youth recruited and interviewed on the streets during a 10-day period by 21 interviewers (11 male, 10 female). The street survey included questions on family background, daily life, institutional experiences, drug use, sexual practices, and AIDS knowledge and attitudes. Interviewers were Brazilian college students and youth workers who attended a 1-week training course. Interviewers worked in pairs at designated locations, and spot-checks were carried out by two roving supervisors. Interviewers approached all youth in their assigned location, explained the study, and invited them to participate. At the end of the interview youth received a meal ticket redeemable at local restaurants.

Because identifying information was obtained only after youngsters agreed to be interviewed and was optional, the exact participation rate is unknown. Tallies kept by interviewers indicate that $62 \%$ of the youngsters completed the interview. A total of 413 interviews were administered. Examination of identifying information and interviewers' descriptions of participants revealed that 32 respondents were interviewed more than once. Two others were over the cut-off age of 18 .
Repeated and over-age interviews were excluded, leaving 379 respondents. The final sample consisted of 291 boys (mean age 13.9 years) and 88 girls (mean age 14.6 years).

Data processing and analysis.-Qualitative data were transcribed and analyzed by topic. Triangulation of the data sets revealed a high degree of consistency in information obtained by different methods. Examples cited in this paper were selected to illustrate group patterns of experience.

Data from the structured interviews were analyzed using SPSS. The interview data were used to explore patterns of experience described by youngsters living or working on the street, and the qualitative data to illustrate the findings. Analyses were conducted to reveal differences between subgroups of street youth, boys and girls, and youth of different ages. Significant differences are reported when found; otherwise, group data are presented.

\section{Results}

\section{Subgroups of Street Youth}

During in-depth interviews, informants were asked to describe a typical day for a working street youth (menino trabalhador) and a homeless street youth (menino de rua). A 15-year-old boy described a working street youth's day as follows:

If he's in school, he goes to school and when classes end, he buys peanuts and asks his mother to roast them. Then, he goes to the soccer field or plays cards until 5:30, when he goes out to sell [the peanuts] and gets home at 4:00 A.M.

Homeless youth spend their days very differently:

When we go to sleep it's about 5 in the morning; we wake up around 2 or 3 in the afternoon. You wake up, get up, wash your face, if you have money you have breakfast, 
TABLE 2

Primary Sleeping location, Degree of Family Contact, and Survival ACtivities, by AGE Group (Percentages)

\begin{tabular}{|c|c|c|c|c|}
\hline & \multicolumn{3}{|c|}{ AGE Group (Years) } & \multirow[b]{2}{*}{$\begin{array}{c}\text { Total } \\
(N=378)\end{array}$} \\
\hline & $\begin{array}{c}9-12 \\
(N=103)\end{array}$ & $\begin{array}{c}13-15 \\
(N=176)\end{array}$ & $\begin{array}{c}16-18 \\
(N=94)\end{array}$ & \\
\hline \multicolumn{5}{|l|}{ Primary sleep location: } \\
\hline Home & 65.0 & 42.6 & 14.1 & 41.3 \\
\hline Street ………...................... & 17.5 & 42.0 & 60.6 & 40.2 \\
\hline Other ……………............. & 17.5 & 15.3 & 25.3 & 18.5 \\
\hline \multicolumn{5}{|l|}{ Family contact: } \\
\hline Frequent ........................ & 72.5 & 49.7 & 30.5 & 51.1 \\
\hline 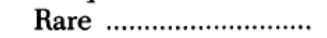 & 27.5 & 50.3 & 69.5 & 48.9 \\
\hline \multicolumn{5}{|l|}{ Survival activities: } \\
\hline Legal only ….................... & 82.0 & 50.6 & 23.5 & 51.9 \\
\hline 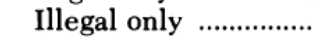 & 6.0 & 19.2 & 43.9 & 22.2 \\
\hline Legal and illegal ....... & 12.0 & 30.2 & 32.7 & 25.9 \\
\hline
\end{tabular}

NOTE.-Mantel-Haenszel chi-squares significant for each of the three variables, $p<.00001$.

go out to steal, then you start to sell the stuff and the money all goes on drugs, because in the street it's all drugs! . . . Then, you get high, you're all set, then you come down and sleep. [Male, 16]

The distributions of where youth slept, degree of family contact, and survival activities were examined in the street survey data. Overall, the sample was fairly evenly divided between youth who slept at the home of parents or relatives and those who slept on the street, between youth with daily or weekly family contact and those with occasional or no contact, and between youth engaging in legal as opposed to illegal survival activities (Table 2). With increasing age, more youth reported sleeping on the street, having less family contact, and being involved in illegal activities (Table 2). The only gender difference was in usual sleeping place; equal proportions of girls and boys slept on the street, but fewer girls slept at home (30\% vs. $45 \%)$ and more in other locations such as hotels or the homes of nonrelatives $(30 \%$ vs. $15 \%), \chi^{2}(2,379)=11.4, p<.004$.

The three variables were interrelated. Most youth who slept at home $(N=156)$ had frequent family contact (84.5\%) and engaged in legal survival activities only (83.0\%). In contrast, few youth who slept on the street $(N=152)$ had frequent family contact $(17.5 \%)$ or engaged in legal survival activities only (22.4\%).

The sample was divided into "home-based" and "street-based" youth, corresponding to the "on" and "of" the street distinction made in the literature. Home-based youth were those who slept at home $(N=156)$ and those who slept in other nonstreet locations but had frequent family contact and did not engage in illegal survival activities $(N=20)$. Street-based youth were those who slept on the street $(N=152)$, and those who slept in other locations but had rare family contact and/or engaged in illegal activities $(N=48)$. The age and gender distribution of the two types of youth is displayed in Table 3 .

\section{Social Networks and Resources}

Family situation.-The survey data revealed a diminished family presence for street-based youth. Street-based youth were slightly more likely than home-based youth to be from another part of the state $(30.5 \%$ vs. $20 \%)$ or another state (18\% vs. 9\%) rather than from Belo Horizonte (Table 4). Perhaps because of this, these youngsters were less likely to have parents, siblings, or other family members in the same city; in addition, fewer street-based youth had two living parents (Table 4).

Parental absence or death might precipitate going to the street, either directly or by the resulting strain on family members, as youth described:

I myself came to the street when I was 6 , when my mother died. I would walk around the street; then I met up with the boys and stayed with them. [Male, 17]

I couldn't stand to live at home anymore. My mother liked to hit us, she wouldn't let us go out, we didn't have any freedom . . . my mother wouldn't let us stay home one single day, we had to work. She was alone, she had separated from my father. [F., female, 22] 
TABLE 3

Gender and Age Distribution of Home-based and STREET-BASED Youth (Percentages)

\begin{tabular}{|c|c|c|c|}
\hline & $\begin{array}{c}\text { Home } \\
(N=176)\end{array}$ & $\begin{array}{c}\text { Street } \\
(N=200)\end{array}$ & $\begin{array}{c}\text { Significance } \\
\left(\chi^{2}\right)\end{array}$ \\
\hline Gender .............. & & & N.S. \\
\hline Male ............... & 79.0 & 75.0 & \\
\hline Female ......... & 21.0 & 25.0 & \\
\hline Age group ....... & & & $p<.0001$ \\
\hline $9-12$ & 42.0 & 14.0 & $\ldots$ \\
\hline $13-15 \ldots \ldots . .$. & 47.7 & 46.0 & $\cdots$ \\
\hline $16-18 \ldots \ldots . .$. & 10.2 & 40.0 & \\
\hline
\end{tabular}

No gender differences emerged, but with increasing age fewer street-based youth reported having relatives in the same city.

Social resources.-Fewer street- than homebased youth had someone to give them a place to sleep, protection, or help in case of injury or illness. No age differences emerged, but fewer street-based boys than girls had social resources (Table 5).

Additional analyses (not shown) revealed that street-based youth were more likely to seek help from nonrelatives. For example, the 123 streetbased youth who had someone to find them a place to sleep were more likely than the 156 home-based youth to turn to a peer $(25 \%$ vs. $5 \%)$ or a nonrelated adult ( $30 \%$ vs. $18 \%)$ rather than a relative $(45 \%$ vs. $72 \%), \chi^{2}(2,279)=23.9, p<.00005$.

Going hungry.-Street-based youth were more likely than home-based youth to ever go hungry (Table 5). No age differences emerged, but more street-based boys than girls went hungry.

Living with nonrelatives.-More street- than home-based youth reported ever living with nonrelatives (Table 5), and additional analyses re- vealed differences in whom they had lived with. Among street-based youth who had lived with nonrelatives $(N=127), 44 \%$ had last lived with peers, $40 \%$ with adult friends, family friends, or substitute families, $10 \%$ in institutions, and $6 \%$ with employers. In comparison, among homebased youth $(N=38), 13 \%$ had lived with peers, $50 \%$ with adult friends, family friends, or substitute families, $8 \%$ in institutions, and $29 \%$ with employers, $\chi^{2}(3,164)=23.1, p<.00005$. More home-based girls than boys had lived with nonrelatives, primarily because they were more likely to have been in domestic service.

Peer networks.-Nearly two thirds of the street-based youth belonged to a turma (group or gang), with more street- than home-based boys belonging (Table 5). The qualitative materials reveal that the turma is a close-knit group that provides youngsters with support, companionship, and protection. Group solidarity is enforced by various mechanisms. Members of a turma create a private language using code words, gestures, and letter substitutions. New members have to steal and prove their willingness to abide by group norms, and norm breakers are punished, with the ultimate punishment being the ronda

TABLE 4

Family Situation of Home-based and Street-Based Youth (Percentages)

\begin{tabular}{|c|c|c|}
\hline & $\begin{array}{l}\text { Home-based } \\
(N=176)\end{array}$ & $\begin{array}{l}\text { Street-based } \\
(N=200)\end{array}$ \\
\hline Born in Belo Horizonte (BH) ........ & 71.1 & 51.8 \\
\hline Parents in $\mathrm{BH}$ & 93.8 & $64.0^{\mathrm{a}}$ \\
\hline 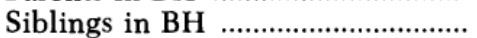 & 95.4 & $76.6^{\mathrm{a}}$ \\
\hline Other relatives in $\mathrm{BH}$ & 87.4 & $64.3^{\mathrm{a}}$ \\
\hline Both parents alive & 69.3 & $37.5^{\mathrm{a}}$ \\
\hline
\end{tabular}

a Differences between home- and street-based youth, controlling for age, Mantel-Haenszel $\chi^{2}, p<.05$. 
TABLE 5

Social Resources of Home-based and StreEt-based Youth, By Gender (Percentages)

\begin{tabular}{|c|c|c|c|c|c|c|}
\hline & \multicolumn{3}{|c|}{ HOME-BASED } & \multicolumn{3}{|c|}{ STREET-BASED } \\
\hline & $\begin{array}{c}\text { Girls } \\
(N=37)\end{array}$ & $\begin{array}{c}\text { Boys } \\
(N=139)\end{array}$ & $\begin{array}{c}\text { Total } \\
(N=176)\end{array}$ & $\begin{array}{c}\text { Girls } \\
(N=50)\end{array}$ & $\begin{array}{c}\text { Boys } \\
(N=150)\end{array}$ & $\begin{array}{c}\text { Total } \\
(N=200)\end{array}$ \\
\hline Someone helps sleep ......... & 83.8 & 90.6 & 89.1 & 78.0 & $56.0^{\mathrm{ab}}$ & $61.5^{\mathrm{c}}$ \\
\hline 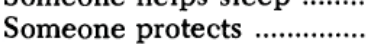 & 97.3 & 88.5 & 90.3 & 76.0 & $60.7^{\mathrm{b}}$ & $64.5^{c}$ \\
\hline Someone helps if hurt ....... & 94.6 & 95.7 & 95.5 & 92.0 & $76.0^{\mathrm{ab}}$ & $80.0^{c}$ \\
\hline 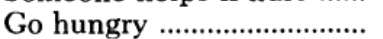 & 27.0 & 20.9 & 22.2 & 38.0 & $55.7^{\mathrm{ab}}$ & $51.3^{\mathrm{c}}$ \\
\hline Lived with nonrelatives ... & 51.4 & $15.8^{\mathrm{a}}$ & 23.3 & 68.0 & $62.7^{\mathrm{b}}$ & $64.0^{\mathrm{c}}$ \\
\hline Belong to gang & 55.9 & $29.2^{\mathrm{a}}$ & 34.5 & 57.1 & $65.1^{\mathrm{b}}$ & $63.1^{\mathrm{c}}$ \\
\hline
\end{tabular}

${ }^{a}$ Differences between girls and boys within type (home-based and street-based), controlling for age, MantelHaenszel $\chi^{2}, p<.05$.

${ }^{\mathrm{b}}$ Differences between home-based and street-based youth within gender, controlling for age, Mantel-Haenszel $\chi^{2}, p<.05$.

${ }^{\mathrm{c}}$ Differences between home-based and street-based youth, controlling for age, Mantel-Haenszel $\chi^{2}, p<.05$.

("circle"), a ritual involving violence, torture, and gang rape.

Institutional experiences.-Because they conduct their daily lives in public, street youth often come to the attention of welfare or correctional authorities. The majority of street-based youth (particularly boys) had been in the state child welfare agency, juvenile court, and juvenile prison (Table 6). Contact with these institutions was described as resulting from arrest for law-breaking, vagrancy, or during one of the city's periodic "clean-up" operations. More rarely, sick youth self-refer to the child welfare agency for medical care, or parents turn their children over to the state if unable to care for or control them.

More street- than home-based youth (particularly boys) reported contacts with religious and government service agencies (Table 6). These or- ganizations typically provide meals and access to showers as well as laundry, recreational, and medical facilities. All youngsters were equally likely to have ever attended school (Table 6). However, more home- than street-based youth were currently attending school at each age group: 9-12year-olds, $60 \%$ vs. $4 \%$; $13-15$-year-olds, $51 \%$ vs. $19 \%$; $16-18$-year-olds, $22 \%$ vs. $12.5 \%$.

\section{Daily Activities}

Survival activities.-When survey respondents were asked how they earned money, 52\% reported legal activities (working, begging), 22\% illegal activities (stealing, exchanging sex for money), and $26 \%$ both.

The majority of home-based youth $(91.5 \%)$ and two-fifths of street-based youth worked at unskilled jobs to earn money legally. Home-based

TABLE 6

Institutional Experiences of Home-based and Street-based Youth, by Gender (Percentages)

\begin{tabular}{|c|c|c|c|c|c|c|}
\hline & \multicolumn{3}{|c|}{ HOME-BASED } & \multicolumn{3}{|c|}{ STREET-BASED } \\
\hline & $\begin{array}{c}\text { Girls } \\
(N=37)\end{array}$ & $\begin{array}{c}\text { Boys } \\
(N=139)\end{array}$ & $\begin{array}{c}\text { Total } \\
(N=176)\end{array}$ & $\begin{array}{c}\text { Girls } \\
(N=50)\end{array}$ & $\begin{array}{c}\text { Boys } \\
(N=150)\end{array}$ & $\begin{array}{c}\text { Total } \\
(N=200)\end{array}$ \\
\hline Child welfare agency ....... & 43.2 & 40.3 & 40.9 & 60.0 & $86.5^{\mathrm{ab}}$ & $79.8^{\mathrm{c}}$ \\
\hline Juvenile court ………........... & 10.8 & 15.8 & 14.8 & 42.0 & $68.5^{\mathrm{ab}}$ & $61.8^{\mathrm{c}}$ \\
\hline Juvenile prison ....................... & 13.5 & 9.4 & 10.2 & 56.0 & $63.8^{\mathrm{b}}$ & $61.8^{\mathrm{c}}$ \\
\hline Religious agencies ............. & 27.0 & 25.9 & 26.1 & $62.0^{\mathrm{b}}$ & $80.0^{\mathrm{ab}}$ & $75.5^{\mathrm{c}}$ \\
\hline Government agencies ...... & 2.7 & 12.9 & 10.8 & 18.0 & $45.3^{\mathrm{ab}}$ & $38.5^{\mathrm{c}}$ \\
\hline Ever in school ....................... & 97.3 & 95.7 & 96.0 & 90.0 & 88.0 & 88.5 \\
\hline
\end{tabular}

a Differences between girls and boys within type (home-based and street-based), controlling for age, MantelHaenszel $\chi^{2}, p<.05$.

${ }^{\mathrm{b}}$ Differences between home-based and street-based youth within gender, controlling for age, Mantel-Haenszel $\chi^{2}, p<.05$.

${ }^{\mathrm{c}}$ Differences between home-based and street-based youth, controlling for age, Mantel-Haenszel $\chi^{2}, p<.05$. 
TABLE 7

Legal SuRvival ACtivities Reported by Home-Based AND STREET-BASED Youth (Percentages)

\begin{tabular}{|c|c|c|}
\hline & $\begin{array}{l}\text { Home-based } \\
(N=161)\end{array}$ & $\begin{array}{l}\text { Street-based } \\
\quad(N=80)\end{array}$ \\
\hline 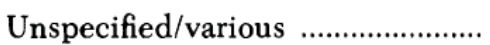 & 14.9 & 16.3 \\
\hline Street vendor & 37.3 & 10.0 \\
\hline 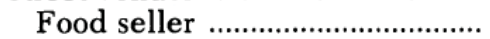 & 14.9 & 2.5 \\
\hline Newspaper seller .......................... & 5.6 & 1.25 \\
\hline Other (e.g., flowers, toys) & 16.8 & 6.25 \\
\hline Street work & 38.5 & 65.0 \\
\hline Wash cars & 21.7 & 31.1 \\
\hline 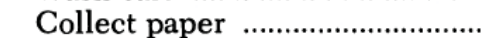 & 7.5 & 20.0 \\
\hline Other (e.g., carry groceries) ...... & 9.3 & 13.8 \\
\hline Domestic employment ...................... & 6.8 & 3.8 \\
\hline Formal/semiqualified ......................... & 2.5 & 5.0 \\
\hline
\end{tabular}

NOTE. $-\chi^{2}(4,241)=24.0, p<.0001$.

youth were more likely to be street vendors and street-based youth to engage in work requiring no capital, such as washing cars or collecting paper to sell (Table 7). Not surprisingly, girls were more likely to work in domestic settings than boys.

Most street-based youth (75\%) and some home-based youth $(14.8 \%)$ engaged in illegal survival activities; $76 \%$ stole, $8.5 \%$ exchanged sex for money, and $15 \%$ did both. Informants said that youngsters are drawn into illegal activities because of the low and unpredictable income generated by street jobs and because they learn from more experienced street youth. To examine the relation between time on the street and involvement in illegal activities, analysis of variance (controlling for current age) was conducted. Youth engaging in illegal activities had been on the street significantly longer than those not involved in illegal activities, $M=5.0$ vs. 3.3 years, $F(1,353)=9.1, p<.005$.

Problem, behaviors.-Lifetime and current use of alcohol, injecting drugs, and seven common "street drugs" (inhalants like paint thinner and shoemaker's glue; marijuana; lolo, a mixture of ether and perfume; cough syrup; amphetamines; cocaine; and hallucinogenic teas) was assessed. Street-based youth were more likely than home-based youth to report lifetime and current use of alcohol and drugs, and lifetime injecting drug use (Table 8).

Life history interviews corroborated that drug use is ubiquitous on the street:
When I came to the street, I was well received; we began to make money like crazy and that got me more involved in the street; we were always selling jewelry, whatever, and going up the hill to get high. [F., female, 22]

Informants said street youth use drugs for a variety of reasons. Drugs make street life bearable by dulling hunger (inhalants are cheaper than food), helping youngsters forget their problems, and giving youth courage to steal and face the dangers of the street. Drug dependency is common, as shown in this extract from field notes:

I was in the square, the kids were sniffing thinner. L.A. was very agitated because the can had finished. L.R. said, "Look at that, just because the thinner's gone, he's in the mood, the first necklace that appears, he'll grab it." D.R. added, "It's true, when the thinner's gone they all get nervous until they get money for another can; when they buy it they ... are calm again."

Sexual activity was assessed during the street survey. Over four-fifths of street-based youth, compared to under half of home-based youth, had initiated sexual activity, with higher proportions in each age group (Table 8). During in-depth and life history interviews and focus groups, youth described a world where sex fulfills multiple needs (survival, pleasure, comfort, dominance) and where multiple partners (both adults and peers from inside and outside the social group) are common (for a full analysis, see Raffaelli et al., 1993). 


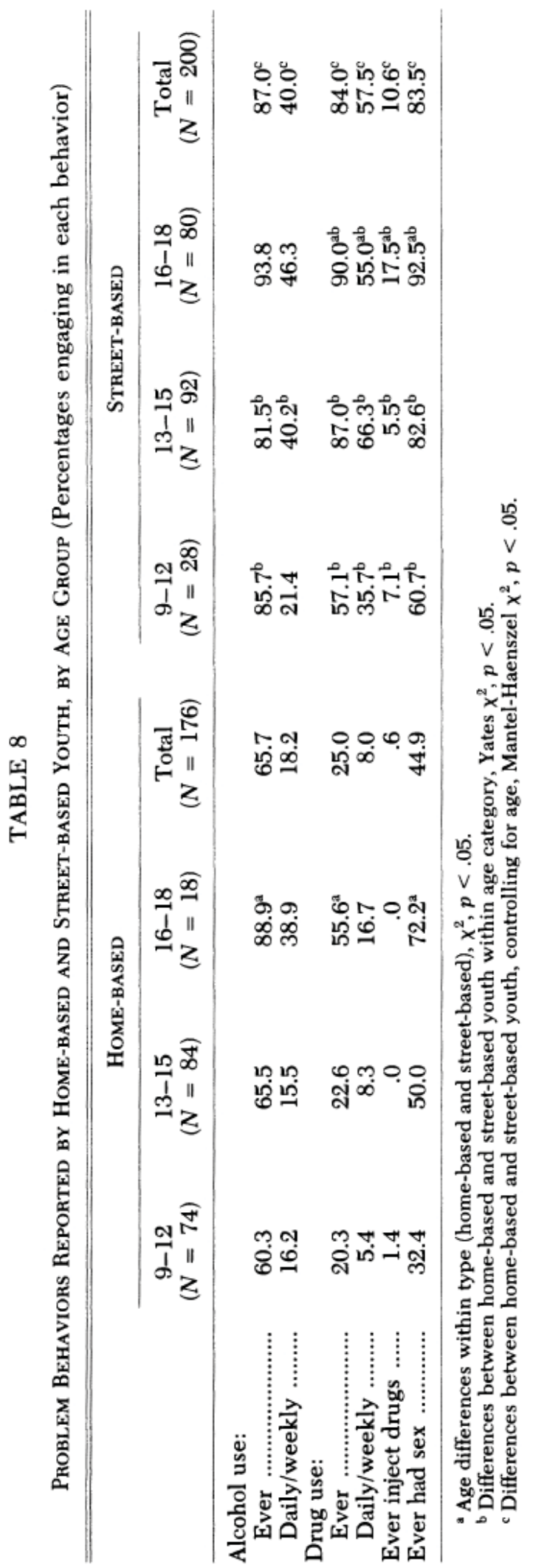




\section{Discussion}

Street youth, who are all too visible on city streets around the world, have seldom been the focus of developmental research. Our analysis of social and behavioral contexts experienced by homeless and working street youth uncovered differential patterns that will probably have an impact on developmental trajectories.

\section{Children "On" the Street}

Working youth are coping with developmental tasks while contributing to the well-being of their impoverished families. The majority of working youngsters we interviewed had established support networks, and many were attending school. Although some youth supplemented their income by engaging in illegal activities, most had not been involved with the police or judicial system. The fact that two-fifths of working youth had been in the child welfare agency is not evidence of delinquency, since parents may turn children over to the state temporarily during times of family problems (Rizzini \& Rizzini, 1991).

One possible source of developmental stress for these youngsters is having to work from an early age. Child labor has been eradicated in many countries because it interferes with schooling and can be physically and emotionally injurious. However, how individuals interpret a potentially stressful event determines their reaction to it; if interpreted positively, it can contribute to a sense of mastery and competence (Trad \& Greenblatt, 1990). Prior research suggests that, for poor children in developing countries, starting to work at an early age may not be completely negative. Working makes poor children feel useful and productive (de Moya, 1989) and enables them to contribute to the family economy (Barker \& Knaul, 1991), and opting to work rather than attend school does not have deleterious effects on future earning potential (Rizzini \& Rizzini, 1991).

Another potential source of stress for working youth is exposure to the risks and temptations of the street. However, our findings suggest that many youngsters avoid engaging in problem behaviors. Although one-quarter of the working youth had tried drugs, patterns of current use suggest experimentation rather than steady use. Going to the street does appear to be linked to earlier onset of sexual activity compared to the general population (Pathfinder International, 1991), but fewer home- than street-based youth were sexually active at all age groups. Finally, although age and time on the street were associated with involvement in illegal activities, the smaller proportion of older working youth cannot be interpreted solely as evidence of a progression to "becoming" street youth, because working youth typically leave the street to take up formal employment as they approach adulthood (Rizzini \& Rizzini, 1991).

Few gender differences in everyday experiences emerged among home-based youth. More girls had been in domestic service, and so had lived at the home of nonrelatives, and girls were more likely to belong to gangs, perhaps as a means of protecting themselves while engaged in street work. Overall, however, boys and girls reported similar circumstances. In sum, working youth appear to be experiencing orderly development within their larger socioeconomic context.

\section{Children "Of" the Street}

Homeless street youth experience very different social networks and daily activities. They live in a world of decreased adult presence, increased importance of the peer group, drug and alcohol abuse, and early onset of sexual activity. Street youth display many strengths as they struggle to survive (e.g., Aptekar, 1989; Tyler, Tyler, Echeverry, \& Zea, 1991); however, they also show hallmarks of psychological and physical risk (e.g., Childhope, 1990; Lusk, 1989).

Parental absence has been identified as one of the most significant sources of childhood stress (Arnold, 1990). Over three-fifths of the street youth we interviewed had lost one or both parents, and most reported only rare family contact. Abusive or neglectful parents have been linked to emotional and behavioral outcomes that may persist into adulthood (Johnson \& Cohn, 1990); during in-depth interviews and focus groups many youngsters revealed that they had been abused or neglected at home. The presence of stable support networks of extended family members, teachers, or neighbors can make up for parental absence or neglect (Trad \& Greenblatt, 1990). However, many street-based youth did not have adults to turn to in times of trouble, relying instead on peers, institutions, or strangers.

In addition to lacking stable adult figures, street youth are exposed to a variety of major life events (e.g., leaving home, arrest, violence) and minor hassles during their daily struggle to survive: 
It's very difficult, life on the street; you have to steal; if you don't steal you don't eat. You have to be able to run or the police will get you. You have to risk your life in exchange for food, clothes. [Male, 17]

Continued exposure to multiple life stressors has been linked to negative long-term outcomes (e.g., Compas, Howell, Phares, Williams, \& Giunta, 1989; DuBois, Felner, Brand, Adan, \& Evans, 1992).

One of the strengths street youth demonstrate is the ability to form groups that perform many functions usually fulfilled by the family (Barker \& Knaul, 1991). Peers are important socializing agents in most cultures (e.g., Rubin, 1980), but in most cases their influence is balanced by that of parents. The turma is an important survival mechanism; untempered by adult controls, however, gangs set up a strict code of loyalty and honor, punishing norm breakers harshly and allowing no recourse to a higher authority.

The social and behavioral contexts of street youths' lives are probably linked to negative developmental outcomes. Researchers have found high levels of psychological disturbance among homeless youth in the United States (Fox, Barrnett, Davies, \& Bird, 1990), Australia (Hier, Korboot, \& Schweitzer, 1990), and Latin America (Aptekar, 1989; de Oliveira, 1990). Because psychopathology in childhood predicts a syndrome of adverse adult outcomes (Rutter, 1989), street youth will probably experience long-term difficulties. What happens to street youth when they grow up is largely unknown but thought to be grim; one study found that $80 \%$ of Sao Paulo's prison population consisted of former street youth (Childhope, n.d.).

Street youth are also at physical risk from their substance abuse and sexual activity. The heavy substance use we found is corroborated by other studies (e.g.. Childhope, 1990; de Oliveira, 1990) and may be linked to neurological deficits (e.g., Aptekar, 1989). Other negative outcomes include premature pregnancy and sexually transmitted diseases (International Council on Adolescent Fertility, 1991). Finally, street youth are at risk of injury and death (Childhope, 1991; Dimenstein, 1990). The dangers of street life were apparent in our project, where six (5\%) of 119 youth tracked by one field-worker died during a $1 \frac{1}{2}$-year period.

Homeless boys and girls showed similar patterns of life experiences, but differences emerged suggesting that boys have lower levels of social support and higher levels of institutional support than girls. Due to the higher number of male youth on the street, most service programs are geared to boys (Lusk, 1989), so street girls may be especially vulnerable to exploitation if they lack social resources.

Some authors depict street youth as carefree Huck Finns who are better off than their peers in the slums (e.g., Aptekar, 1988). While many youngsters go to the street to escape difficult family circumstances, it is evident that the street is not a positive developmental context. One young woman had the following message for girls who were thinking of leaving home:

I think they should go back home, try to study, get a job, take care of their bodies and I think they shouldn't get involved with street kids. I say this as a friend because the street is nothing, you get involved because at first everything is marvelous, but in the end when you go to look it's all ugly, finished. [F., 22]

\section{Limitations and Directions for Future Research}

This study has a number of limitations. First, it is difficult to evaluate how representative the sample was, although the congruence between our findings and those from prior research (e.g., Rizzini \& Rizzini, 1991) indicate that the sample was fairly typical. Second, the reliance on self-report methods means that data on sensitive topics may be distorted; however, use of multiple methods of data collection permitted triangulation and verification of findings. Third, because data were gathered in one city, caution must be taken in generalizing the findings. Finally, because the study was cross-sectional, no conclusions about long-term development can be drawn. The study does permit identification of several topics whose investigation would increase our understanding of the developmental implications of being a street youth.

First, given the scope of the street youth problem, in-depth descriptive studies of the ecological contexts of youngsters' lives are urgently needed to identify risk and protective factors that drive some youth out of the home and into the street. Second, information is needed on the long-term consequences of early entry into the work force. It has been suggested that one outcome may be premature character structuring that allows little room for growth and change (Elkind, 1981). 
Again, given that so many youngsters in developing countries work at unskilled jobs from an early age and that socioeconomic conditions in these countries will not change in the near future, research on the developmental effects of child labor is needed.

Finally, the millions of children and adolescents found on the streets of large cities represent a population that has been virtually ignored by developmental researchers, including those who focus on catastrophic or chronic stress (e.g., Garmezy \& Masten, 1990; Turkel \& Eth, 1990). The systematic documentation of social, behavioral, and psychological contexts of street youths' daily lives would not only yield valuable information about development under adverse life circumstances but also enhance our understanding of normative developmental processes. Perhaps most important, by integrating street youth into the mainstream of developmental psychology, we can begin to understand and help them.

\section{References}

Alves, A. J. (1991). Meninos de rua e meninos da rua: Estrutura e dinamica familiar [Children on the street and children of the street: Family structure and dynamics]. In A. Fausto \& R. Cervini (Eds.), O trabalho e a rua: Criancas e adolescentes no Brasil urbano dos anos 80 (pp. 117-132) [Work and the street: Children and adolescents in urban Brazil during the 80s]. Sao Paulo: Cortez.

Aptekar, L. (1988). Street children of Cali. Durham, NC: Duke University Press.

Aptekar, L. (1989). Characteristics of the street children of Colombia. Child Abuse and Neglect, 13, 427-437.

Arnold, L. E. (1990). Childhood stress. New York: Wiley.

Barker, C, \& Knaul, F. (1991). Exploited entrepreneurs: Street and working children in developing countries (Childhope Working Paper No. 1). New York: Childhope USA.

Bronfenbrenner, U. (1979). The ecology of human development. Cambridge, MA: Harvard University Press.

Cervini, R., \& Burger, F. (1991). O menino trabalhador no Brasil dos anos 80 [Child workers in urban Brazil in the 80s]. In A. Fausto \& R. Cervini (Eds.), O trabalho e a rua: Criancas e adolescentes no Brasil urbano dos anos 80 (pp. 17-46) [Work and the street: Children and adolescents in urban Brazil during the 80s]. Sao Paulo: Cortez.

Childhope. (n.d.). Fact sheet on street children. New York: Author.
Childhope. (1990). Fact sheet on street children and drug abuse. New York: Author.

Childhope. (1991). Fact sheet on violence against street children. New York: Author.

Compas, B. E., Howell, D. C, Phares, V., Williams, R. A., \& Giunta, C. T. (1989). Risk factors for emotional/behavioral problems in young adolescents: A prospective analysis of adolescent and parental stress and symptoms. Journal of Consulting and Clinical Psychology, 57, 732-740.

Damon, W. (1983). Social and personality development. New York: Norton.

Dimenstein, G. (1990). A guerra dos meninos: Assassinatos de menores no Brasil [The war of the children: Assassinations of minors in Brazil]. Sao Paulo: Brasiliense.

DuBois, D. L., Felner, R. D., Brand, S., Adan, A. M., \& Evans, E. G. (1992). A prospective study of life stress, social support, and adaptation in early adolescence. Child Development, 63, 542-557.

Elkind, D. (1981). The hurried child: Growing up too fast too soon. Reading, MA: Addison- Wesley.

Fox, S. J., Barrnett, R. J., Davies, M., \& Bird, H. R. (1990). Psychopathology and developmental delay in homeless children: A pilot study. Journal of the American Academy of Child and Clinical Psychiatry, 29, 732-735.

Garmezy, N., \& Masten, A. (1990). The adaptation of children to a stressful world: Mastery of fear. In L. E. Arnold (Ed.), Childhood stress (pp. 459-473). New York: Wiley.

Hier, S. J., Korboot, P. J., \& Schweitzer, R. D. (1990). Social adjustment and symptomatology in two types of homeless adolescents: Runaways and throwaways. Adolescence, 25, 761-771.

International Council on Adolescent Fertility. (1991). Reaching sexually exploited youth. Passages, 10, $1-2$.

Johnson, C. F., \& Cohn, D. S. (1990). The stress of child abuse and other family violence. In L. E. Arnold (Ed.), Childhood stress (pp. 267-295). New York: Wiley.

Jovens miseraveis no Brasil ja chegaram a 17 milhoes [Impoverished youth in Brazil already total 17 million]. (1990, December 19). Jornal do Brasil, p. 1.

Kimchi, J., \& Schaffner, B. (1990). Childhood protective factors and stress risk. In L. E. Arnold (Ed.), Childhood stress (pp. 475-500). New York: Wiley.

Kranzler, E. M. (1990). Parent death in childhood. In L. E. Arnold (Ed.), Childhood stress (pp. 405-421). New York: Wiley.

Lusk, M. W. (1989). Street children programs in Latin America. Journal of Sociology and Social Welfare, 16, 55-77.

Moya, E. A. de. (1989, September). The long and wind- 
ing guazabara road and/or the kingdom of exiles. Paper presented at the First Dominican Congress on the Minor under Especially Difficult Circumstances, Santo Domingo, Dominican Republic.

de Oliveira, W. (1990). Street kids in Brazil: An exploratory study of medical status, health knowledge and the self. Unpublished master's thesis. University of Minnesota.

Pathfinder International. (1991). Saude reprodutiva do adolescente: Pesquisa em cinco cidades, Brasil1987/1989 [Reproductive health of adolescents: Research in five Brazilian cities-1987/1989]. Salvador: Policrom.

Payne Merritt, A., \& Raffaelli, M. (1993). Creating a model HIV prevention program for street youth. Child, Youth, and Family Services Quarterly, 16, $7-$ 9.

Raffaelli, M., Campos, R., Payne Merritt, A., Siqueira, E., Antunes, C. M., Parker, R., Greco, M., Halsey, N., \& the Street Youth Study Group. (1993). Sexual practices and attitudes of street youth in Belo Horizonte, Brazil. Social Science and Medicine, 37, 661-670.

Rizzini, I., \& Rizzini, I. (1991). Menores institucionalizados e meninos de rua: Os grandes temas de pesquisas na decada de 80 [Institutionalized minors and street youth: The great research topics of the 80s]. In A. Fausto \& R. Cervini (Eds.), O trabalho e a rua: Criancas e adolescentes no Brasil urbano dos anos 80 (pp. 69-90) [Work and the street: Children and adolescents in urban Brazil during the 80s]. Sao Paulo: Cortez.

Roberts, A. R. (Ed.). (1974). Childhood deprivation. Springfield, IL: Thomas.

Rubin, A. (1980). Children's friendships. Cambridge, MA: Harvard University Press.

Rutter, M. (1989). Pathways from childhood to adult life. Journal of Child Psychology and Psychiatry, 30, 23-51.

Trad, P. V., \& Greenblatt, E. (1990). Psychological aspects of child stress: Development and the spectrum of coping responses. In L. E. Arnold (Ed.), Childhood stress (pp. 23-49). New York: Wiley.

Turkel, S. B., \& Eth, S. (1990). Psychopathological responses to stress: Adjustment disorder and posttraumatic stress disorder in children and adolescents. In L. E. Arnold (Ed.), Childhood stress (pp. 51-71). New York: Wiley.

Tyler, F. B., Tyler, S. L., Echeverry, J. J., \& Zea, M. C. (1991). Making it on the streets in Bogota: A psychosocial study of street youth. Genetic, Social, and General Psychology Monographs, 117, 395-417.

UNICEF. (1989). Annual report. New York: UNICEF. 